\title{
Upaya menigkatkan kompetensi guru dalam menyusun rencana pelaksanaan pembelajaran melalui pemberdayaan kegiatan kelompok kerja guru
}

\author{
Pitasari Pitasari*) \\ Sekolah Dasar Negeri 04 Air Pura
}

\begin{tabular}{l}
\hline Article Info \\
\hline Article history: \\
Received April $17^{\text {th }}, 2021$ \\
Revised May $06^{\text {th }}, 2021$ \\
Accepted Jun $23^{\text {rd }}, 2021$ \\
\hline
\end{tabular}

\section{Keyword:}

Kompetensi guru Silabus

RPP

Supervisi akademik

\begin{abstract}
Jenis penelitian ini adalah penelitian tindakan kepala sekolah. Penelitian ini dilaksanakan pada bulan September 2018 UPT SDN 04 Air Pura Kecamatan Air Pura Kebupaten Pesisir Selatan. Penelitian ini ditujukan kepada semua guru yang ada di UPT SDN 04 Air Pura Kecamatan Air Pura Kebupaten Pesisir Selatan yang berjumlah sebanyak 14 orang. Teknik analisis data dianalisis secara deskriptif dengan menggunakan rumus persentase. Bedasarkan hasil penelitian diperoleh bahwa : 1) Untuk meningkatkan kompetensi dalam proses pembelajaran dilakukan melalui pemberdayaan kegiatan kompetensi dalam proses pembelajaran dilakukan melalui pemberdayaan kegiatan kelompok kerja guru secara berkala sebanyak 2 siklus, tiap siklus 2 kali pertemuan, tiap pertemuan malakuakan 4 tahap kegiatan yang dari perencanaan, pelaksanaan tindakan, pengamatan dan refleksi. 2) Obsevasi dilakukan kepala sekolah sebagai kolaborator pengawas, diakhiri dengan refleksi untuk melihat segi positif dan negative sabagai landasan perencanaan tindakan berikutnya pada siklus 2. Dengan supervise klinis terjadi peningkatan kompetensi guru pada awal kegiatan $71.43 \%$ menjadi $93.73 \%$ terjadi peningkatan sebasar $22,30 \%$.
\end{abstract}

(c) 2021 The Authors. Published by IICET.

This is an open access article under the CC BY-NC-SA license (https://creativecommons.org/licenses/by-nc-sa/4.0

\section{Corresponding Author:}

Pitasari Pitasari

Sekolah Dasar Negeri 04 Air Pura

Email: 1snt1@.ccu.edu.tw

\section{Pendahuluan}

Pengembangan sumber daya manusia pendidikan, khususnya pengambangan profesionalisme guru, merupakan usaha mempersiapkan guru agar memiliki berbagai wawasan, pengetahuan, keterampilan dan memberikan rasa percaya diri untuk melaksanakan tugas dan kewajibannya sebagai petugas professional. Pengembangan atau peningkatan kemampuan professional harus bertolak pada kebutuhan permasalahan nyata yang di hadapi oleh guru agar bermakna.

Undang-undang RI Nomor 14 tahun 2005 tentang guru dan dosen mengamanatkan guru untuk: (i) memiliki kualifikasi akademika minimum S1/D4;,(ii); memiliki kompetensi sebagai agen pembelajaran yaitu kompetensi pedagogic, kepribadian, social, dan professional; dan (iii) memiliki sertifikasi pendidikan. Agar guru dapat memiliki kompetensi sabagai agen pembelajaran sebagaimana yang diamantakan pada UU tersebut diatas, maka guru harus mengingkatkan kompetensinya melalui barbagai upaya antara lain melalui pelatihan, penulisan karya tulis ilmiah, dan berbagai pertemuan di kelompok kerja atau forum (Kelompok Kerja Guru (KKG). 
Secara teoritis dan fungsi Kelompok Kerja Guru ( KKG ) merupakan wadah dalam pembinaan professional guru yang dapat dimanfaatkan untuk berkomunikasi, bertukar fikiran dan berbagai pengalaman, melaksanakan berbagai demontrasi, atraksi dan simulasi dalam pembelajaran. Dalam wadah ini para guru dapat membahas permasalahan dari mereka untuk mereka.

Namun fenomena dilapangan tergambar bahwa keberadaan Kelompok Keja atau forum tersebut keberadaanya belum memberikan konstirbusi yang signifikan terhadap peningkatan kompetensi guru. Berbagai kendala yang dihadapi oleh guru, kepala sekolah dan pengawas saat ini dalam usaha menciptakan kelompok kegiatan yang aktif dan efektif adalah usaha berikut: (1). Manajeman kelompok kerja msaih perlu ditingkatkan kualitasnya dalam upaya optimalisasi intesifikasi pembinaan kegiatan kelompok kerja: (2). Program-program kegiatan kelompok kerja masih kurang sesuai dengan kebutuhan pengembangan operasional belum memadai dan kurang dimanfaatkan secara tepat; (4). Bervariasinya perhatian dan konstribusi pemerintah daerah melalui dianas pendidikan terhadap program dan kegiatan kelompok kerja. Oleh karena itu perlu upaya untuk merevitalisasi kelompok kerja tersebut agar aktivitas/kegiatan yang dilakukan oleh kelompok kerja atau forum tersebut dapat memberikan manfaat dalam upaya peningkatan kompetensi guru. Hal tersebut diatas diharapkan dapat memberi konstribusi untuk menumbuh kembangkan budaya pembelajaran yang berpusat pada system instruksional yang prima, sehingga berdampak pada peningkatan kualitas pembelajaran yang berujung pada peningkatan kualitas pendidikan nasional.

Dilihat dari sisi lain kemampuan guru dalam mengembangkan rencana palaksanaan pembelajaran yang digunakan dalam proses pembelajaran seahari-hari masih relatif rendah, RPP hanya sebagai dokumentasi bagi guru, tidak digunakan sesuai prosedur yang sudah mereka buat sebelum proses pembelajaran dilaksanakan, sehinngga tidak tertanam didalam Mind Set guru bahwa RPP sangat penting sebagai pedoman dalam melaksanakan pembelajaran dikelas.

Peranan kepala sekolah untuk mengoptimalkan kegiatan kelompok kerja guru sangat penting, dalam hal ini di setiap pertemuan yang dilakukan harus ada sesuatu yang baru yang didapatkan oleh guru, seperti fenomena di atas masih banyak guru yang masih kurang professional dalam membuat rencana pelaksanaan pembelajaran, dengan ikut serta kepala sekolah membina guru dalal menyusun RPP sesuai dengan prosedur dan stndar yang ada akan meningkatkan kualitas guru terutama dalam menyusun RPP, dan kualitas pembelajaran dapat meningkat.

Berdasarkan hal diatas penulis tertarik untuk malaksanakan sebuah penelitian yang berjudul " upaya meningkatkan komptensi guru UPT SDN 04 Air Pura Kecamatan Air Pura dalam menyusun Rencana Pelaksanaan Pembelajaran Melalui Pemberdayaan Kegiatan Kelompok Kerja Guru Di UPT SDN 04 Air Pura Kecamatan Air Pura Kebupaten Pesisir Selatan.

\section{Metode}

Jenis penelitian ini adalah penelitian tindakan sekolah (PTS). Penelitian ini dilakukan pada bulan September 2020 di UPT SDN 04 Air Pura Kecamatan Air Pura Kabupaten Pesisir Selatan.Penelitian ini ditujukan kepada semua guru yang ada di UPT SDN 04 Air Pura Kecamatan Air Pura Kabupaten Pesisir selatan yang sejumlah sebanyak 16 orang. Langkah-langkah PTS yaitu: perencanaan, pelaksanaan, pengamatan,dan refleksi

Penelitian tindakan ini melibatkan 16 orang guru memberi motivasi ini perlu dilakukan kerena pemberi motivasi oleh kepla sekolah kepada guru-guru sangat jarang dilaksanakan, dalam hal ini penelitian membuat perencanaan lembar observasi aktivitas yang dilakukan oleh guru dan aktifitas yang dilakukan oleh kepala sekolah. Kegiatan ini dilakukan dalam dua siklus sehingga guru dinilai memiliki motivasi yang baik dalam pembelajaran. Dalam setiap siklus supervisor melakukan observasi dan penilaian terhadap perkembengan kemampuan setiap guru terutama peningkatan motivasi kerja. Pelaksanaan kegiatan dilakukan sebanyak dua siklus, yang terdiri dari 4 kali pertemua, dua kali siklus I dan dua pertemuan siklu II.

Penelitian diawali dengan cara memberikan kuisioner tentang motivasi kerja kepada guru, kemudian guru mengumpulkan kembali kepada kepala sekolah, bedasarkan data tersebut supervisor melakukan pembinaan kepada guru sesuai dengan kesulitan masing-masing guru dalam rangka meningkatkan motivasi kerja guru dengan menggunakan metode diskusi kelompok.

Dalam kegiatan refleksi ini, Pembina/supervisor bersama dengan guru-guru melakukan diskusi tentang langkah-langkah meningkatkan motivasi dalam melaksanakan tugas. Dalam kegiatan ini juga dibicarakan berbagai permasalahan yang disarankan oleh para guru termasuk kendala serta manfaat yang disarankan terhadap perubahan motivasi setelah diberikan pembinaan oleh kepalsa sekolah hasil yang diperolah dari 
kegiatan refleksi ini akan dijadikan sebagian bahan perencanaan dan tindakan yang akan dilakukan pada siklus berikutnya.

Teknik pengumpulan data dilakukan dengan cara pengisian lembaran observasi salam proses tendakan penelitian oleh supervisor sehingga akan diperoleh data kualitatif sebagai hasil penelitian.

Instrument penelitian yang akan digunakan adalah lembaran observasi yang digunakan oleh supervisor untuk mencatat perkembangan kemampuan masing-masing guru yang dibinanya selama proses penelitian (siklus 1 dan siklus 2). Lembar observasi yang digunakan dalam penelitian ini.

Tenik analisis data dilakukan terhadap hasil motivasi kerja guru sebagai data awal kemampuan guru dan hasil observasi yang dilakukan selama proses pembinaan akan di analisis secara deskriptif untuk mengukur keberhasilan proses pembinaan sesuai dengan tujuan penelitian tindakan sekolah ini.

Analisis data dilakukan terhadap data yang telah diredukasi baik data perencanaan,pelaksanaan, maupun data evaluasi. Analisis data ini dilakukan dengan cara terpisah-pisah, hal ini dilakukan agar dapat ditemukan berbagai informasi yang spesifik dan terfokus pada bebagai informasi yang mendukung pembelajaran dan mengahambat pembelajaran. Data tentang aktifitas observasi kegiatan yang dilakukan guru dihitung dengan rumus persentase Sudijono (2011:43).

\section{Hasil dan Pembahasan}

Penelitian ini adalah penelitian tindak sekolah (PTS) yang telah dilaksanakan secara berkolaboratif seluruh guru kelas di UPT SDN 04 Air Pura Kecamatan Air Pura Kabupaten Pesisir Selatan. Hasil dan pembahasan dari pelaksanaan penelitian tindakan sekolah ini akan dipaparkan sebagai berikut :

\section{Hasil Penelitian}

Penelitian tindakan sekolah ini dilaksanakan dalam 2 siklus, bedasarkan wawancara penulis dengan beberapa orang guru di UPT SDN 04 Air Pura Kecamatan Air Pura Kabupaten Pesisir Selatan banyak guru-guru yang belum mampu dalam penyusunan rencana pelaksanaan pembelajaran dengan efektif. Berikut ini sesuai dengan perencanaan yag disusun dengan tahapan sebagai berikut:

\section{Siklus I}

1. Perncanaan

Pada tahap perncanaan penelitian menyusun rencana pelaksanaan perbaikan dengan membagi guru dalam beberapa kelompok untuk mempersiapkan format dan instrument lainnya. observasi yang diperlukan dalam penelitian ini adalah penelitian dilaksanakan di masing-masing Kelompok Kerja Guru (KKG) yang nantinya kepala sekolah akan memberikan dan bimbingan dari aspek apa saja guru yang masih lemah dalam penyusunan rencana pelaksanaan pembelajaran nantinya.

\section{Pelaksanaan}

Pelaksanaan penelitian tindakan sekolah ini dilakukan di UPT SDN 04 Air Pura Kecamatan Air Pura Kabupaten Pesisir Selatan yang dilaksanakan pada bulan September 2018 berkaitan dengan usaha peningkatan kompetensi guru kepala sekolah sudah melaksanakan program pemberdayaan kegiatan keolmpok kerja guru. Kepala sekolah mengoservasi kelas secara lansung dan mengamati cara guru mengajar. Apakah guru sudah menguasai meteri atau belum, mengamati media dan metode yang diguanakan .Disamping ini kepala sekolah memiliki program lain yaitu diadakan diskusi kelaompok, $\mathrm{KKG}$, rapat guru melihat RPP dan silabus.

Kegiatan diawali dengan mendiskusikan tetang permasalahan yang dihadapi dalam menyusun RPP melalui kelompok yang dilanjutkan dengan penyampaian informasi tetang cara menyusun RPP serta memebrikan contoh model menyususn RPP yang baik sesuai dengan prosedur yang telah ditentukan dan sesuai dengan standar yang sudah ada. Masing - masing kelompok mengakaji contoh model menyusun system penilaian yang diberikan, kemudian menetapkan format menyususn sistem penilaian yang digunakan. Setelah menyepakati format yang digunakan guru melalui sistem menyusun sistem penilaian dalam kelompok sekolah masing-masing.

\section{Pengamatan}

Hasil pengamatan observasi berkaitan dengan kompetensi guru dalam menyusun perencanaan pembelajaran melalui pemberdayaan kegiatan kelompok kerja guru diperoleh hasil observasi dilihat dari ketersediaan dalam dan kelengkapan silabus terlihat pada petermuan 1 sebanyak 9 orang (64,29\%) sedangkan pada pertemuan 2 sebanyak 11 orang $(78,57 \%)$ dalam hal ini tidak terjadi peningkatan 
kemampuan guru dalam melengkapi silabus, kemampuan guru dalam melengkapi RPP sudah termasuk dalam kategori baik yaitu pada pertemuan 1 sebanyak 7 orang $(50,00 \%)$ sedangkan pada pertemuan 2 tidak terjadi peningkatan yaitu masih sebanyak 8 orang $(57,14 \%)$.

Pada aspek ketersediaan guru pada bahan ajar pada pertemuan 1 sebanyak 6 orang $(42,86 \%)$ sedangkan pada pertemuan 2 sebanyak 9 orang $(64,29 \%)$ dalam aspek ini terjadi peningkatan kemampuan guru dalam aspek ketersediaan guru pada bahan ajar sebanyak $21,43 \%$. Aspek ketersedian dan kelengkapan instrument evaluasi pada pertemaun 1 sebanyak 7 orang $(50,00 \%)$, pada pertemuan 2 sebanyak 10 orang $(71,43 \%)$. Pada aspek ketersedian guru pada program pendukung pertemuan 1 sebanyak 10 orang $(71,43 \%)$ terlihat pada pertemuan 2 sebanyak 12 orang $(85,71 \%)$, dalam hal ini terjadinya peningkatan kemampuan guru dalam program pendukung.

4. Refleksi

Pelaksanaan kegiatan belajar mengajar pada siklus 1 masih terdapat kekurangan, sehingga perlu adanya revisi untuk dilakukan pada siklus berikutnya. Kesulitan yang dilakukan guru adalah pada aspek 1) ketersediaan dan kelengkapan silabus, 2) ketersediaan dan kelengkapan RPP, 3) ketersediaan dan kelengkapan Instrumen Evaluasi. Hasil penilitian menunjukan hanya pada aspek kelengkapan bahan ajar dan ketersediaan program pendukung yang mengalami peningkatan. Namun hasil yang diharapkan belum dapat tercapai pada siklus 1 ini maka akan dilanjutkan pada siklus II.

\section{Siklus II}

Pada siklus II kegiatan yang dilakukan adalah melakukan kegiatan penyempurnaan KKG yang dapat memperbaiki perecanaan pembelajaran guru dan melakukan refleksi dan evaluasi. Penelitian memberikan pengarahan dan bimbingan sesuai hasil observasi yang dilaksanakan pada siklus 1 dimana aspek-aspek apa saja yang perlu ditingkatkan sehingga kompetensi guru dapat meningkatkan sesuai dengan apa yang diharapkan. Untuk lebih jelas dapat diuraikan sebagai berikut:

\section{Perencanaan}

Perencanaan penilitian siklus II ini tidak jauh berbeda dengan siklus I yang telah dilakukan diatas, namun pada siklus II ini peneliti atau kepala sekolah tetap menyediakan lembar observasi berkaitan dengan proses pembinaan yang dilakukan sesuai dengan jadwal yang telah ditentukan sebelumnya, sebelum melakukan observasi kepala sekolah terlebih dahulu memberi tahu kepada guru yang bersangkutan bahwa observasi akan dilaksanakan pada tanggal dan jam yang telah ditentukan, sehingga guru dapat mempersiapkan diri sebelumnya.

\section{Pelaksanaan}

Pelaksanaan dilakukan setelah lembar observasi disusun dan dipersiapkan, proses pembibingan dilakukan dengan tujuan meningkatkan kompetensi guru di dalam proses pembelajaran, sehingga guru lebih termotivasi dalam mengajar.

Dalam proses pelaksanaan penelitian tentunya tidak semua guru dapat menangkap apa yang telah diberikan proses pembibingan, namun begitu peneliti yang berperan sebagai kepala sekolah mempunyai kewajiban dan tanggung jawab dalam membina semua guru-guru terutama dalam proses pembelajaran. Pelaksanaan kegiatan belajar mengajar untuk siklus II dilaksanakan pada bulan September 2020 di UPT SDN 04 Air Pura Kecamatan Air Pura Kabupaten Pesisir Selatan dengan jumlah guru sebanyak 16 orang.

Kegiatan diawali dengan mendiskusikan tentang permasalahan yang dihadapi dalam menyusun RPP serta memberikan contoh model penyususnan RPP yang baik sesuai dengan prosedur yang telah ditentukan dan sesuai dengan standar yang sudah ada. Masing-masing kelompok mengkaji contoh model menyusun sistem penilaian yang diberikan, kemudian menetapkan format menyusun sistem penilaian yang digunakan. Setelah menyepakati format yang digunakan guru ,mulai menyusun sistem penilaian dalam kelompok sekolah masing-masing.

\section{Observasi}

Setelah dilakukan pembinaan kepada guru-guru sesuai dengan permasalahan yang ditentukan di lapangan kemudian kepala sekolah masuk ke dalam kelas kembali dengan tujuan malakukan observasi berdasarkan pembinaan yang dilakukan, kepala sekolah sudah menyiapkan lembar observasi sesuai dengan proseduran yang telah ditetapkan. 
Dari hasil observai terhadap sikap guru pada siklus II banyak mengalami perubahan bahkan guru lebih meningkatkan kerja samanya. Hasil observasi siklus II dapat disajikan hasil obeservasi dilihat dari ketersediaan dan kelengkapan selabus pada pertemuan 1 sebanyak 14 orang (87.50\%) sedangkan pada pertamuan 2 masih sebanyak 16 orang (100\%) dalam hal ini terjadi peningkatan kemampuan guru dalam kategori sangat baik yaitu pada pertemuan 1 sebanyak 13 orang $(81,25 \%)$ sedangkan pada pertemuan 2 terjadi peningkatan yaitu sebanyak 15 orang $(93,75 \%)$.

Pada aspek ketersediaan guru pada bahan ajar pada pertemuan 1 sebanyak 11 orang $(68,75 \%)$ sedangkan pada pertemuan 2 sebanyak 13 orang $(81,25 \%)$ dalam aspek ini terjadi peningkatan kemampuan guru dalam aspek ketersediaan guru dalam aspek ketersediaan guru pada bahan ajar sebanyak $12.50 \%$ dan termasuk dalam kategori sangat baik.

Aspek ketersediaan dan kelengkapan instrument evaluasi pada pertemuan 1 sebanyak 15 orang (93,75\%), pada pertemuan 2 sebanyak 15 orang (93,75\%). Pada aspek ketersediaan guru pada program pendukung terlihat pada pertemuan 1 sebanyak 16 orang (100\%) sedangkan pada pertemuan 2 sebanyak 16 orang $(100 \%)$, dalam hal ini terjadi peningkatan kemampuan guru dalam pada program pendukung.

4. Refleksi

Memperhatikan hasil pada siklus II melakukan refleksi terhadap hasil yeng diperoleh penelitian pada siklus II ini sudah baik dan tidak ditemukan lagi kekurangan-kekurangan guru dalam proses pembelajaran, namun penelitian tidak mengungkiri bahwa masih ada beberapa guru yang belum melakukan perubahan yang signifikan, bedasarkan hasil penelitian yang dilakukan apa yang diharapkan sudah sesuai dengan apa yang telah direncanakan sebelumnya, sehinga penelitian ini dihentikan pada siklus II.

\section{Pembahasan}

Hasil penelitian membuktikan bahwa terdapat peningkatan kompetensi guru dalam proses pemebelajaran dimana berdasarkan hasil observasi yang dilakukan terdapat peningkatan kompetensi guru bedasarkan pembelajaran melalui pemberdayaan kegiatan kelopmpok kerja guru di UPT SDN 04 Air Pura Kecamatan Air Pura Kabupaten Pesisir Selatan.

Guru memiliki pengaruh luas dalam dunia pendidikan. Di sekolah dia adalah pelaksana administrasi pendidikan yaitu bertanggung jawab agar pendidikan dapat berlansung dengan baik. Guru wajib memiliki kualitas akademi, kompetensi, sertifikat pendidikan, sehat jasmani dan rohani, serta memiliki kemampuan untuk mewujudkan tujuan pendidikan nasional.

Istilah kompetensi berasal dari interest. Dalam kemus bahasa Inggris Indonesia, kompetensis berate wewenang. Menurut Majid (2005:6) menjelaskan kompetensi yang dimiliki oeleh setiap guru akan mengujudkan kualitas guru dalam mengajar. Kompetensi tersebut akan terwujud dalam menjalakan fungsinya sebagai guru. Sejalan dengan itu Mulyasa (2006:38) mengartikan kompetensi sebagai penguasaan terhadap suatu tugas ketrampilan, sikap, dan apresiasi yang diperlukan untuk menunjang keberhasilan. Sofo (1999:123) mengemukakakn "A competency is composed of skill,knowledge, and attitude, but to the standard of performance required in employment", dengan kata lain kompetensi tidak hanya mengandung pengetahuan keterampilan, dan sikap, namun yang penting adalah penerapan dari pengetahuan, ketrampilan, dan sikap yang diperlukan tersebut dalam pekerjaan.

Kompetensis sebagai ability, yaitu kapasitas seorang individu untuk mengerjakan berbagai tugas dalam suatu pekerjaan. Selajutnya dikatakan bahwa kemampuan individu dibentuk oleh dua factor, yaitu factor kemampuan intelektual dan kemampuan fisik. Kemampuan intelektual adalah kemampuan yang diperlukan untuk melakukan kegiatan mental sedangkan kemampuan fisik adalah kemampuan yang diperlukan untuk melakukan tugas-tugas yang menutut stamina, kecekatan, kekuatan, dan ketrampilan. Selanjutnay Mulyasa ( dalam Musfah.2011:27) bahwa kompetensi guru merupakan perpaduan antara kemempuan personal, keilmuan,teknologi,social,dan spiritual yang secara kafah membentuk kompetensi standar profesi guru.

\section{Simpulan}

Bedasarkan hasil penelitian dan pembahasan yang telah diuraikan secara lengkap pada bab sebelumnya dapat ditarik kesimpulan sebagai berikut : 1) Untuk meningkatkan kompetensi dalam proses pembelajaran dilakaukan melalaui pemberdayaan kegiatan kelompok kerja guru secara berkala sebanyak 2 siklus, tiap siklus 2 kali pertemuan, tiap pertemuan melakukan 4 tahap kegiatan yang dimulai dari perencanaan, pelaksanaan tindakan, pengamatan dan refleksi; 2) Observasi dilakukan kepala sekolah sebagai kolaborator pengawas, diakhiri dengan refleksi untuk melihat segi positif dan negative sabagai landasan perencanaan tidakan 
berikutnya pada siklus 2 . Dengan supervise klinis terjadi peningkatan kompetensi guru pada awal kegiatan $71.43 \%$ menjadi $93.73 \%$ terjadi peningkatan

\section{Referensi}

Bafal,I. (2003).Peningkatan Profesionalisme Guru.Jakarta : Bumi Aksara Bolligton, R. Hopkins, D., \& West, M. (1990). An Introduction to Teacher Appraisal. London :

Cassell.Brown, G.Alih Bahasa Laurens K..(1991).Pengajaran Mikro, Program Ketapilan Mengajar.Surabaya : Erlanga

Cece Wijaya, dkk. Upaya Pembaharuan Dalam Pendidikan Dan pengajaran. Bandung:Rineka Cipta

E. Mulyasa. (2008). Menjadi Guru Profesional, Menciptakan Pembelajaran Kreatif dan Menyenangkan. Bandung: Remaja Rodakarya

E. Mulyasa. (2007)..standar kompetensi dan Sertifikasi Guru..(Bandung: Remaja Rosdakarya Hamzah B. Uno. (2007). Profesi Kependidikan (Problem, solusi dan reformasi Indonesia. Jakarya: Bumi Aksara Hasibuan \& Moedjiono. (2004). Proses Belajar Mengajar. Bandung : Remaja Rosda karya Moh. User Usman. (2005). Mejadi Guru Profesional .( Bandung:PT Remaja Rosdakarya Remaja Rosdakarya. Syaiful Sagala. (2009). Kemampuan Profesional Guru dan tenaga kependidikan, Bandung:Alfabeta. Syaiful Sagala. (2009). Kemampuan Profesional Guru dan tenaga kependidikan, Bandung:Alfabeta.

Trianto,dkk. (2006). Tinjauan Yuridis Hak serta Kewajiban Pendidikan Menurut UU Guru dan Dosen.Jakarta: Persentasi Putaka

Undang-Undang Sistem Pendidikan Nasional No. 20 tahun 2003, Bandung: Citra utama 